TWO NEW METHODS OF FIGHTING INJURIOUS INSECTS.*

\author{
By Prop. A. J. Cook.
}

The Codling Moin has been, and is, the most serious pest to the American pomologist. All previous remedies have only destroyed the Imago insect, after the larva of the same had destroyed the apples. London Purple, applied as a liquid mixture, one pound of the poison to 100 gallons of water, sprinkled on the trees once in May and again in June, has saved the fruit of the following season. Upon picking the fruit in August, the most delicate chemical test could find none of the poison on the apples.

Bisulphide of carbon, so excellent in fighting museum pests, and so much es:eemed as a sprcitic against the grape phyloxera in Europe has been tried by the author of the paper to destroy the Cabbage Maggots, Anthomyia brassicie, and other insects which infest subterranean stems, etc., with excellent success,

A hole is inade in the ground, the liquid poured in and the hole quickly filled with earth, which is pressed down with the foot. The hole is made with a small rod, close to the plant, and about a table spoon-full of the liquid poured into each hole.

\section{SOME OF THE INFUSORIA FOUND IN FRESH POND, CAIHBIDGE.*}

BY S. P. SHAKPLES.

This paper was a general review of observations on the water of Fresh Pond, as delivered in the City of Cambridge. These observations extend, at intervals varying from a few days to a month, over three years. Particular attention was called to the fact thit there seems to be a marked petiodicity in the forms of life in the water, some appearing at certain seasons and then disappearing agait,. This periodicity is not always annual, but may embiace a period of time covering several years. Atlention was called to the necessity of continued observation of at watter in order to minderstand its character. The periodical lad taste of certain wallers

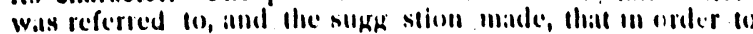
discover the ratuse of this, extemded obscegvatlons were ne-

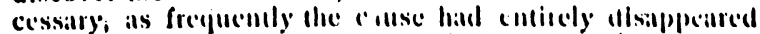

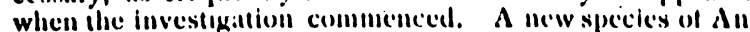
nurea observed in the pond, was descibled as follows: Annurea Longirustris, louica, witu four anterior alid une posterior spine; lhr.e of the anterior spiı.es short about balt the length of tue lorica; the fourth twice the length of the lorics; the posterior of the same length as the long anterior, otherwise resembling Annurea Stipata, though more slender.

\section{BOOKS RECEIVED.}

THE METRIC SYS'TEM ANI) INTERCHANGE (OF WEIGHTS AND MEasures. By B. Beach, Jr., and E. N. Gibbons, Principals of the Fith Avenue School of New York City. G. P. Putnam's Sons. New York. 1880.

The metric system has been adopted by all civilized nations except Russia, England and the United States, and its universal adoption is earnestly desired by the educaled and scientific classes of this couniry. It has been adopted or recommended by the National Acidemy of Sciences, the American Metrological Socie:y, the American Association for the Advancement of Science, by the American Society of Civil Engimeers, the United States Coast Survey, the United States Marine Hospital Service, the American Medical Association, the Congress of Ophthalmogists, Dy leading medical societies and journals, by numerous boards of education, college faculties and local scientific societies. It is also our wish that contributors to this journal should, on all occasions, use the metric system, and we have pleasure in direc.ing atten-

- Read before the A. A. A. S., Buston, 1880. tion to the present cheap and handy little manual, written for those desirous of making use of the metric system. As a class-book in schools it will prove very valuable, as rules and examples are given for working out problems for all weights and measures, answers to which are given, on an extra sheet, with each book. We advise all who are undecided as to the policy of using the metric system to read Dr. R. H. Ward's able plea for its introduction in No. 5 of "SCIENCE," published the 3 ist of July last. He concludes with the practical observation that the proper way to introduce it is to use it yourself. We believe the publication of Messrs. Beach and Gibbons's manual will be a great aid in securing its universal use.

Fourteen Weeks in Physics. By J. Dorman Steele, Ph. D., F. G. S., author of "Fourteen Weeks in Natural Science." A. S. Barnes \& Company. New York, Chicago and New Orleans.

This is an excellent elementary work on Physics adapted to the class-roon, written in a happy style to interest the student and well supplied with illustrations. The author employs simple language, which is readily intelligible, and the experiments are within the reach of every pupil. In order to tamiliarize the pupil with the metric system it is constantly employed in the problems. As an introduction to the study of physics we consider this work one of the best for the use of young students.

ThE YOUNG ChENIST, $-A$ book of Laboratory work for beginners. By John II. Appleton, A. M., Pro fessor of Chemistry in Brown University. Second Edition. Price 90 cents by mail. Cowperthwaite \& Co., Philadelphia.

The purpose of this book is to aid in the instruction of pupils in chemistry by the experimental or object method. and the aluthor hits attempted to remove at leas: one ob. jec ion to this method by economizing the time of the in. structor, and we are glacl to admit that the cost of sup. plees hiss been greatly reduced of litte. Professor John II. Appleton claims with truth the following advantages for his work:-lirst, the apparatus described and the supplies called for, are of the simplest character. Second, the experiments are described in clear and simple language, and in direct form; the pupil can hardly fail to pertorm them successfully, even $u$ ithout the special aid of the teacher. Third, dangerous experiments have been excluded. Fourth, the chemical eiements are discussed in a scientific order, which, while it aids the memory, does so upon correct principles. Fifth, formulas and reactions are introduced freely, so that the student learns the new nomenclature and new notation without suspecting it. This work is not an experiment. the first edition hav.ng been used with success by Protessors of great experience.

A SHORT CoURSE in QuAlitative CheMical A.Nalysis. By l'rofessor John H. Appleton, A. M., Brown University. Fourlh Edition. Price, 90 cents by mail. Cowperthwa'te \& Co. I'hiladelphia.

The author has used this work in his own class for many years, and to those who are unable to purchase the more bulky and costly manuals this litıle work will be found of great use. It has the advantage of brevity and compactness. It prescribes the most direct and simple course of analysis, and presents a large number of tormulas and reactions. This wcrk and the "Young Chemist," by the same author, will be found very suitable for those who require a reliable introduction to the study of chemistry. 